\title{
Capability of oxygen-scavenger sachets and modified atmosphere packaging to extend fresh barberry shelf life
}

\author{
Razieh Niazmand ${ }^{1 *}$ (D) and Samira Yeganehzad ${ }^{2}$
}

\begin{abstract}
Background: Barberry has long been used as an herbal remedy since ancient times which is found throughout temperate and subtropical regions of the world. Given the short harvesting season and limited shelf life of the barberry, we evaluated the possibility of using modified atmosphere packaging and oxygen-scavenger sachets to increase its storage period. For this purpose, the physicochemical characterization (antioxidant activity, anthocyanin, phenolic compounds, and ascorbic acid content, acidity, firmness, color, and decay incident) of fresh barberry samples packaged within different atmospheres was investigated over 4 weeks of storage at 4 and $25^{\circ} \mathrm{C}$. The barberries were packaged with low-density polyethylene/polyester (LDPE/PET) films under natural atmosphere (C), $N_{2}$ gas (N), vacuum (V), or in the presence of an oxygen scavenger (OS).
\end{abstract}

Results: The results revealed that with increased storage period, the $\mathrm{O}_{2}$ and $\mathrm{CO}_{2}$ levels inside the packages decreased and increased, respectively. The antioxidant activity and amounts of anthocyanin, phenolic compounds, and ascorbic acid all decreased with increasing storage period. Among the studied atmospheres, the OS and, subsequently, $V$ packages were most capable of maintaining the quality of fresh barberries, with the decay incidence being approximately 30 times lower inside these packages relative to the control. Increasing the storage temperature accelerated the intensity of chemical changes and decay across all samples.

Conclusion: The barberries inside the OS packages stored at $4{ }^{\circ} \mathrm{C}$ (and even at $25^{\circ} \mathrm{C}$ ) still had good sensory properties in terms of chemical properties, texture, and color after 4 weeks. Fortunately, it seems that this packaging technology makes the exportation and delayed consumption of the fresh barberry possible by maintaining its quality.

Keywords: Postharvest quality, Vacuum, Nitrogen atmosphere, Storage, shelf life

\section{Background}

The consumer interest in fresh, long-life, health-promoting food products has grown given the establishment of the modern lifestyle and the natural desire for consuming a healthy diet. A growth has thus been observed in the popularity of fresh fruits and vegetables, which have desirable flavors besides their nutritional characteristics [1]. Micronutrients (e.g., ascorbic acid or vitamin

\footnotetext{
${ }^{*}$ Correspondence: r.niazmand@rifst.ac.ir

${ }^{1}$ Department of Food Chemistry, Research Institute of Food Science and Technology, Mashhad, Iran

Full list of author information is available at the end of the article
}

C), tocopherols (vitamin E), and phytochemicals (e.g., carotenoids; phenolic compounds) are available in fruits, making them a dominating aspect of dietary recommendations for a healthy diet [2]. The risk of developing a variety of chronic diseases is minimized with increased fruit intake owing to the presence of numerous bioactive compounds as well as the absence of synthetic additives [3] as well as the absence of synthetic additives [4].

Following harvesting, fruit quality deteriorates secondary to reactions that take place within living tissues involving chemicals and enzymes [1]. This makes the preservation of fruit quality until reaching the consumer 
extremely vital, with various postharvest treatments having been developed for this purpose [5].

Modified atmosphere packaging (MAP) and active packaging (AP) are two recent evolutions in the field of food preservation, with the former being the focus of many investigations on the postharvest preservation of both fruits and vegetables. MAP involves the use of film packaging to trap a product within modified levels of oxygen and carbon dioxide. Respiration and gas transfer are the key processes responsible for compositional changes that occur within the packaged atmosphere of a natural product [5]. Oliveira et al. [6] reviewed how foodborne pathogens are affected by MAP conditions applied for the preservation of fresh-cut fruits and vegetables. Fagundes et al. [7] looked at inducing a delay in cherry tomato ripening using MAP involving 5\% $\mathrm{O}_{2}+5 \% \mathrm{CO}_{2}+$ balanced $\mathrm{N}_{2}$ inside multilayer plastic bags. Rodriguez and Zoffoli, [8] arrived at the most suitable partial pressures of $\mathrm{CO}_{2} /$ $\mathrm{O}_{2}$ for preserving 'Brigitta' blueberry fruit within MAP. Villalobos et al. [9] examined the quality of fig aroma subjected to cold storage with various types of passive MAP.

Oxygen induces food spoilage via the oxidation of constituents (e.g., lipids and vitamins) and the promotion of microbial growth. The incorporation of oxygenscavenging agents into packaging films can facilitate the continuous elimination of oxygen molecules derived from either the food product or the outer environment [10]. While the residual oxygen present in the headspace can merely be reduced to a potentially destructive level of $0.5-2 \mathrm{vol} \%$ via vacuum packaging or MAP, films containing oxygen-scavenging agents can extend product life by minimizing the oxygen level to $0.1 \mathrm{vol} \%$ [11]. The impact that such oxygen-scavenging materials have on product quality has been explored in several studies. Charles et al. [12] reported that the browning of fresh endives was controlled by the use of an oxygen scavenger, which decreased the transient period to 50\%. Aday and Caner [13] demonstrated that such agents could impede strawberry metabolism and mold growth, reducing product decay by over $50 \%$ and more efficiently maintaining the quality relative to the control.

Berberis vulgaris, commonly known as barberry, is a shrub that grows tart, red berries. The largest amount of seedless barberry grow in Iran and is used as fresh fruit or food additive [14]. The quality of the B. vulgaris crop is adversely affected by water activity, microbial growth, enzyme activity, and pigment alterations secondary to oxidation. Considering the fact that the barberry fruit is only harvested between October and November, postharvest preservation is critical. After harvesting, phenolase and polyphenolase enzymes are released and induce browning by affecting the anthocyanin pigments, damaging both barberry quality and appearance [15].
Hence, the postharvest life of the B. vulgaris fruit is relatively limited, and many processes affect the quality of the product during its ripening. Extending the shelf life of fresh barberry has thus been a continuous challenge to mankind.

To our knowledge, the MAP of fresh barberries has not previously been examined. Thus, this work intended to study the quality changes in fresh barberries packaged in the presence of an oxygen scavenger, nitrogen, or vacuum during refrigerated or shelf storage.

\section{Materials and methods \\ Materials}

Fresh barberries (Berberis vulgaris) were collected from an orchard of the Research Institute of Food Science and Technology (Mashhad, Khorasan Razavi, Iran) in October, The foliage was removed and the barberry seeds were kept in a refrigerator until packaging. A bilayer plastic film ( $45 \mu \mathrm{m}$ thickness) made of low-density polyethylene (LDPE) and polyester (PET, internal layer with a thickness of $12 \mu \mathrm{m}$ ) was procured from Apaden Plast Factory (Mashhad, Razavi Khorasan, Iran). Oxygen-scavenger sachets (capacity of $3000 \mathrm{ml}$ ) were supplied from Basteh Raz Salamat Paya Co. (Tehran, Iran). All chemicals and organic solvents were of analytical grade, having been obtained from either Merck (Darmstadt, Germany) or Sigma-Aldrich Chemical (St. Louis, MO, USA).

\section{Barberry packaging}

Approximately $70 \pm 2 \mathrm{~g}$ of fresh barberries were placed in sterilized bags made of LDPE/PET films. The oxygen permeability and the water vapor transmission rate (Brugger model, Feinmechanik, Germany) of films were $0.248 \mathrm{~g} /$ $\mathrm{m}^{2} \mathrm{~d}$ and $125 \mathrm{~cm}^{3} / \mathrm{m}^{2} \mathrm{~d}$ bar, respectively at $25^{\circ} \mathrm{C}$. Packaging was done under four different atmospheres:

1. Control (C): atmospheric air.

2. $\mathrm{N}_{2}$-enriched atmosphere $(\mathrm{N})$ : air eliminated and replaced with $\mathrm{N}_{2}$ gas $\left(>90 \% \mathrm{~N}_{2}\right)$ using a MAP machine (Henkelman, A200 Gerhardt, Netherlands).

3. Vacuum (V): $90 \%$ of air eliminated with a MAP machine and there were $10 \%$ atmosphere air inside the packages. The composition of remained air inside the packs after packaging was as $21.7 \% \mathrm{O}_{2}$, and $<0.2 \%$ $\mathrm{CO}_{2}$.

4. Oxygen scavenger (OS): oxygen-scavenger sachets placed inside the package walls; atmospheric air $\left(21.7 \% \mathrm{O}_{2}\right.$ and $\left.<0.2 \% \mathrm{CO}_{2}\right)$.

For each of these treatments, 16 packages of barberries were made, and three were evaluated per treatment on a weekly basis until the end of the storage period ( 28 days). 


\section{Headspace gas inside the packages}

To monitor the gas concentrations $\left(\mathrm{O}_{2}, \mathrm{CO}_{2}\right.$, and $\left.\mathrm{N}_{2}\right)$ inside the packages, a portable gas analyzer (AGC MapPak Headspace Gas Analyser, Ireland) was used before opening the packages at each evaluation point. Calibration was done using atmospheric air. Values were expressed as percentages of gases composition in the headspace of packages. It is worthy to mention that the in vacuum packages, the changes of remained air composition were reported.

\section{Physical analyses \\ Weight loss measurement}

The barberry packages were weighed initially and then weekly throughout storage. Equation 1 was used to determine the weight loss (WL) percentage:

$$
W L=100 \times\left(W_{i}-W_{f}\right) / W_{i},
$$

where the initial and eventual sample weights are denoted by $W_{\mathrm{i}}$ and $W_{\mathrm{f}}$, respectively [3].

\section{Color measurement}

Sample photographs were scanned using a desktop scanner (Canon Scan 8400 F). A $3 \times 2 \mathrm{~cm}$ segment of each image (JPEG format; $400 \mathrm{dpi}$ ) was selected using Adobe Photoshop (Adobe Inc., USA). After reducing the noise, the pixel parameters were converted to the $\mathrm{L}^{* *}$ and $\mathrm{a}^{*}$ parameters using Image J (1.40 g) software [16].

\section{Firmness}

The barberry firmness was determined using the 3-mm flat probe of the TA.XT-PLUS Texture Analyzer (Stable Micro Systems Ltd., UK). Compression was applied at $0.5 \mathrm{~mm} / \mathrm{s}$ until reaching $2 \mathrm{~mm}$; we noted the maximum force (Newton) that developed. For each storage time and temperature, 20 measurements were made. The results were expressed in Newton [3].

\section{Chemical and phytochemical analyses}

For the determination of moisture content, an oven (Memmert, Germany) was used to dry the samples at $105{ }^{\circ} \mathrm{C}$ until reaching a stable weight [17]. Titratable acidity was measured according to the AOAC (2005). To determine the ascorbic acid content $(\mathrm{mg} / 100 \mathrm{~g})$, metaphosphoric acid extraction of 2,6-dichlorophenol indophenol dye was performed ahead of spectrophotometry at $500 \mathrm{~nm}$ according to the method of Shivembe and Ojinnaka [18]. To assess the total anthocyanin content (TAC), the $\mathrm{pH}$ differential procedure of the AOAC was followed, as described by Brito et al. [19]. Buffers with adjusted $\mathrm{pH}$ values of 1.0 (potassium chloride) and 4.5 (sodium acetate) were utilized for the evaluation of absorption at 510 and $700 \mathrm{~nm}$, respectively. The level of pigment (mg cyanidin 3-glucoside equivalents per $100 \mathrm{~g}$ ) was determined using Eqs. 2 and 3:

$$
\begin{aligned}
& A=\left(A_{510}-A_{700}\right) p H_{1}-\left(A_{510}-A_{700}\right) p H_{4.5}, \\
& T A C=(A \times \times M W \times D F \times 100) /(\in \times L) .
\end{aligned}
$$

In these equations, MW denotes the molecular weight $(449.2 \mathrm{~g} / \mathrm{mol})$; DF represents the dilution factor; $\mathrm{L}$ is the cuvette path length in $\mathrm{cm}$; and $\varepsilon$ denotes the molar extinction coefficient for cyanidin 3-O- $\beta$-D-glucoside (26,900 L/mol. cm).

A blender was utilized to homogenize the barberries, and a cheese cloth was used to filter the blended samples. The Folin-Ciocalteu procedure described by AhmadianKouchaksaraie and Niazmand [20] was slightly modified and followed to determine the content of total phenolic compounds (TPC) in the barberry extracts. First, the diluted extract $(1.5 \mathrm{ml}$; twofold dilution using distilled water) was added to distilled water $(3.16 \mathrm{ml})$ and FolinCiocalteu reagent $(200 \mu \mathrm{l})$. After mixing for $3 \mathrm{~min}, 20 \%$ $\mathrm{Na}_{2} \mathrm{CO}_{3}(50 \mu \mathrm{l})$ was also added. The mixture absorbance was evaluated at $763 \mathrm{~nm}$ with a UV-Vis spectrophotometer (Shimadzu UV160A, Japan) following $2 \mathrm{~h}$ of incubation at $25{ }^{\circ} \mathrm{C}$ in the dark. The calibration curve was plotted using different gallic acid concentrations. The TPC was reported as mg of gallic acid equivalents (GAE) per $100 \mathrm{~g}$.

For the evaluation of antioxidant properties, we slightly modified the procedure of Soleimanifar et al. [21] and assessed the ability of the constituents to sequester the stable DPPH (2,2-diphenyl-1-picrylhydrazyl) radical. First, the diluted extract $(100 \mu \mathrm{l})$ was mixed with the DPPH solution (3.9 ml; methanol solution of DPPH with absorbance between 0.9 and 1). Then, the mixture was shaken vigorously and the reaction was allowed at $25^{\circ} \mathrm{C}$ in the dark until reaching a steady-state, before measuring the absorbance at $517 \mathrm{~nm}$. The spectrophotometer was set to zero using methanol. Equation 4 was employed to calculate the DPPH radical scavenging capacity percentage $\left(\mathrm{RSC}_{\mathrm{DPPH}} \%\right)$ :

$$
\mathrm{RSC}_{\mathrm{DPPH}} \%=\left(\frac{A_{\text {Control }}-A_{\text {Sample }}}{A_{\text {Control }}}\right) \times 100 .
$$

In this equation, $A_{\text {control }}$ and $A_{\text {sample }}$ denote the absorbance of the control and extract, respectively.

The procedure described by Ahmadian-Kouchaksaraie et al. [22] was slightly modified and employed to conduct the FRAP assay. This method is based on the ability of antioxidants to reduce the ferric tripyridyltriazine 
complex, generating its colored, ferrous compound. Acetate buffer $(300 \mathrm{mM} ; \mathrm{pH}=3.6), 2,4,6$-tripyridyl-striazine (TPTZ; $10 \mathrm{mM})$ solution in $\mathrm{HCl}(40 \mathrm{mM})$, and $\mathrm{FeCl}_{3} \cdot 6 \mathrm{H}_{2} \mathrm{O}(20 \mathrm{mM})$ solution were employed as the stock solutions. A fresh working solution was prepared using acetate buffer $(25 \mathrm{ml})$, TPTZ solution $(2.5 \mathrm{ml})$, and $\mathrm{FeCl}_{3} \cdot 6 \mathrm{H}_{2} \mathrm{O}$ solution $(2.5 \mathrm{ml})$. After mixing, this "FRAP" solution was incubated for half an hour at $37{ }^{\circ} \mathrm{C}$. Then, the barberry extracts $(150 \mu \mathrm{l})$ were added to the fresh FRAP solution $(3 \mathrm{ml})$; this mixture was left in the dark for half an hour. The absorption was then read at $593 \mathrm{~nm}$, with various concentrations of $\mathrm{FeSO}_{4} \cdot 7 \mathrm{H}_{2} \mathrm{O}$ being used in the preparation of the calibration curve.

\section{Decay incidence}

Visual inspection was used to evaluate the decay incidence (DI) at 7, 14, 21 and 28 days of storage. To this end, the fruits that had superficial mold lesions were counted and noted, while those that lacked any sign of decay were regarded as being healthy. Equation 5 was used to calculate the DI in each package [13]:

$$
\text { DI }(\%)=(\text { infected barberries } \times 100) / \text { total barberries. }
$$

\section{Statistical analysis}

In this study, all experiments were performed in three replications. The analysis of the data was done using oneway ANOVA based on a completely randomized, simple design and using Minitab software version 16.2.4. The comparison of means was made using Tukey's test at a 95\% confidence level $(P<0.05)$. The plots were drawn using Microsoft Excel 2013 software.

\section{Results and discussion}

\section{Headspace gas composition inside packages}

The variations in $\mathrm{O}_{2}$ and $\mathrm{CO}_{2}$ levels within the headspace of packages during storage at 4 and $25{ }^{\circ} \mathrm{C}$ are shown in Figs. 1 and 2, respectively. The results revealed that the effect of atmosphere type on $\mathrm{O}_{2}$ and $\mathrm{CO}_{2}$ levels during storage was significant $(P<0.05)$.

Generally, with increasing storage period, the $\mathrm{O}_{2}$ levels inside the packages decreased, while the $\mathrm{CO}_{2}$ levels increased. These changes can be attributed to barberry respiration, chemical interactions, and microbial activities as well as gas diffusion through the LDPE/PET film. Our findings are consistent with those of Candir et al. [23] and Koort et al. [24], where it was reported that $\mathrm{O}_{2}$ and $\mathrm{CO}_{2}$ levels inside the packages decreased and increased to various degrees, respectively, depending on the fruit and film types.

The $\mathrm{O}_{2}$ level inside the OS packages remained minimal (less than one percent) throughout storage, indicating the efficiency of the OS in $\mathrm{O}_{2}$ absorption. This reduced the intensity of oxidative and microbial reactions as well as fermentation, meaning that the $\mathrm{CO}_{2}$ concentration also stayed low.

It is also important to note that in the vacuum packaging, although the volume of air was reduced initially, the gaseous composition remained constant. As the storage period increased, depending on the chemical and microbial interactions, the gas composition changed and the $\mathrm{O}_{2}$ level inside the package decreased. Some reports explain that atmospheres containing low levels of $\mathrm{O}_{2}(1$ to $5 \%$ ) and high concentrations of $\mathrm{CO}_{2}$ (5 to $10 \%$ ) may prolong product life by limiting the conversion of 1-aminocyclopropane-1-carboxylic acid to ethylene [25].

An inverse relationship prevailed between the pressure of $\mathrm{O}_{2}$ and the temperature inside the LDPE packages, such that the pressure decreased with increased temperature. This indicates that the activation energy for film permeability to $\mathrm{O}_{2}$ was less than the activation energy of the fruit. The stability of $\mathrm{O}_{2}$ and $\mathrm{CO}_{2}$ levels is affected by the permeability of the film and the type of fruit, the latter being due to the fact that various fruits have different respiration rates. There are also some conflicting reports suggesting that the respiratory rate is not affected by $\mathrm{CO}_{2}$ levels below $20 \mathrm{kPa}$ [24].

It seems that the $\mathrm{O}_{2}$ and $\mathrm{CO}_{2}$ changes inside the packages were more pronounced at $25^{\circ} \mathrm{C}$ than at $4{ }^{\circ} \mathrm{C}$, which can be due to augmented chemical reaction rates at the higher temperature as well as a more favorable temperature for microbial growth. Giuggioli et al. [26] confirmed that the intensity of changes in $\mathrm{O}_{2}$ and $\mathrm{CO}_{2}$ levels inside fresh blueberry packages was greatly affected by the temperature, such that 3 days of storage at $20{ }^{\circ} \mathrm{C}$ resulted in $70 \%$ greater changes relative to 15 days of storage at $1{ }^{\circ} \mathrm{C}$.

\section{Weight loss}

The preservation of a fruit's net weight until it reaches the consumer is a vital aspect of marketing. In addition to quantity, weight loss impacts texture, appearance, and nutritional quality.

The results show that the atmosphere type had a significant effect on the weight loss of the various barberry packages during 28 days of storage at 4 and $25{ }^{\circ} \mathrm{C}$ (Table 1). The comparison of means revealed that the weight loss significantly increased with extended storage periods at both temperatures $(P<0.05)$. This drop was noticeably more at the higher temperature in all studied packages, which is expectable due to temperature-dependent augmentation of respiration rate, transpiration rate, and microbial activity. Contrary to our findings, Wani et al. [27] found that the weight loss of 


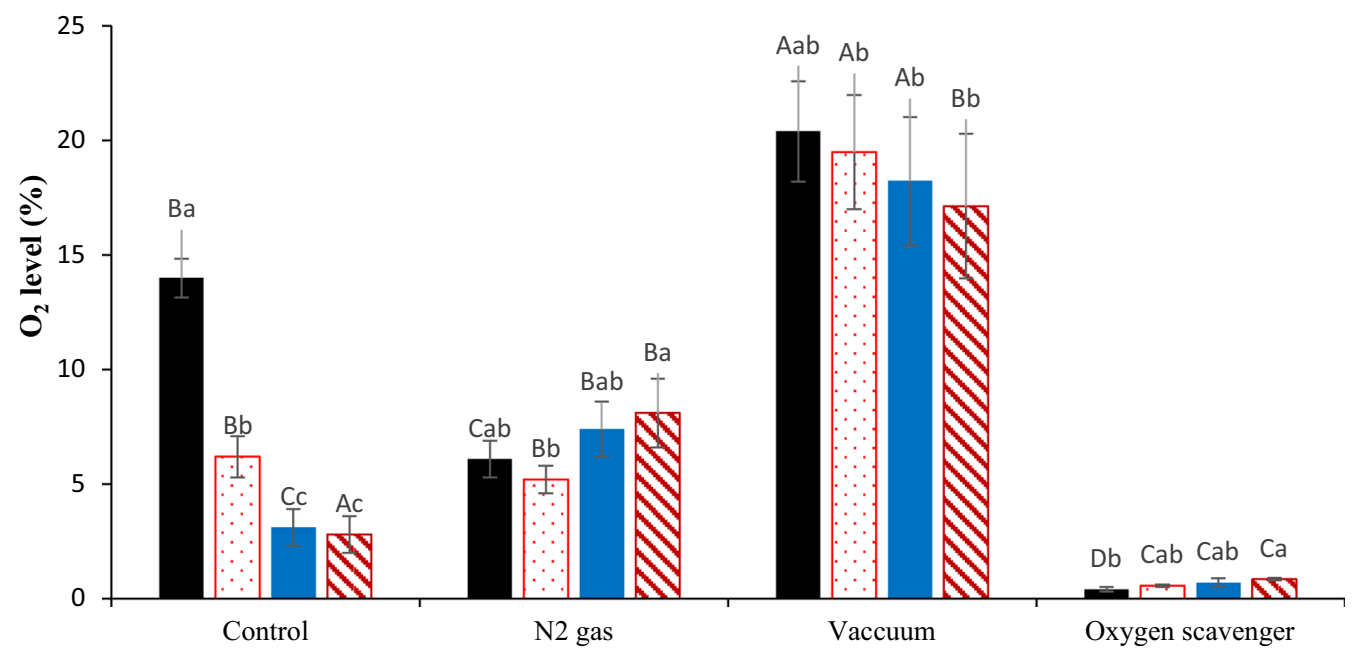

Atmosphere type

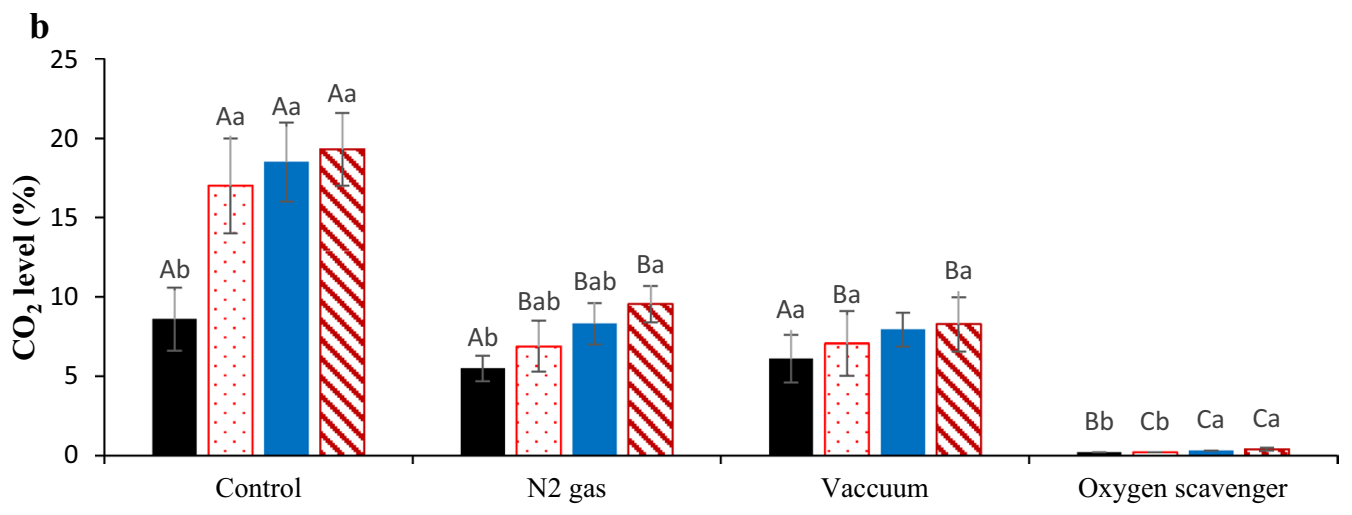

Atmosphere type

Fig. 1 Changes of $\mathbf{a} \mathrm{O}_{2}$ and $\mathbf{b} \mathrm{CO}_{2}$ levels inside the barberry packages under different atmospheres during storage at $4{ }^{\circ} \mathrm{C}$. Error bars show standard deviation (SD). Non-similar uppercase and lowercase letters in each column indicate a significant difference among atmosphere type and storage period, respectively, according to the Tukey test $(P<0.05)$

cherries did not differ significantly between storage at room and refrigerator temperatures.

The results show that at $4{ }^{\circ} \mathrm{C}$, after 7 days, weight loss was less in the OS packages than in the control. With increasing storage period, weight loss in the OS packages occurred slower relative to the other samples, such that after 4 weeks of storage at $4{ }^{\circ} \mathrm{C}$, the OS packages had the least weight loss $(0.94 \%)$, with the $\mathrm{V}$ packages coming second in this regard (1.3\%). This trend was replicated in packages stored at $25{ }^{\circ} \mathrm{C}$, but there was no significant difference in weight loss among the OS, $\mathrm{V}, \mathrm{N}$ and $\mathrm{C}$ packages $(P>0.05)$.

Due to the low permeability of LDPE film to vapor, the air inside a package becomes saturated then supersaturated with water vapor, leading to condensation; this vastly impacts the product's shelf life. Weight loss also can occur due to evaporation and cross-respiration (producing water and heat). Moreover, respiration induces weight loss through the consumption of carbon atoms. Minimized weight loss at lower temperatures can be 
a

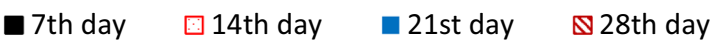
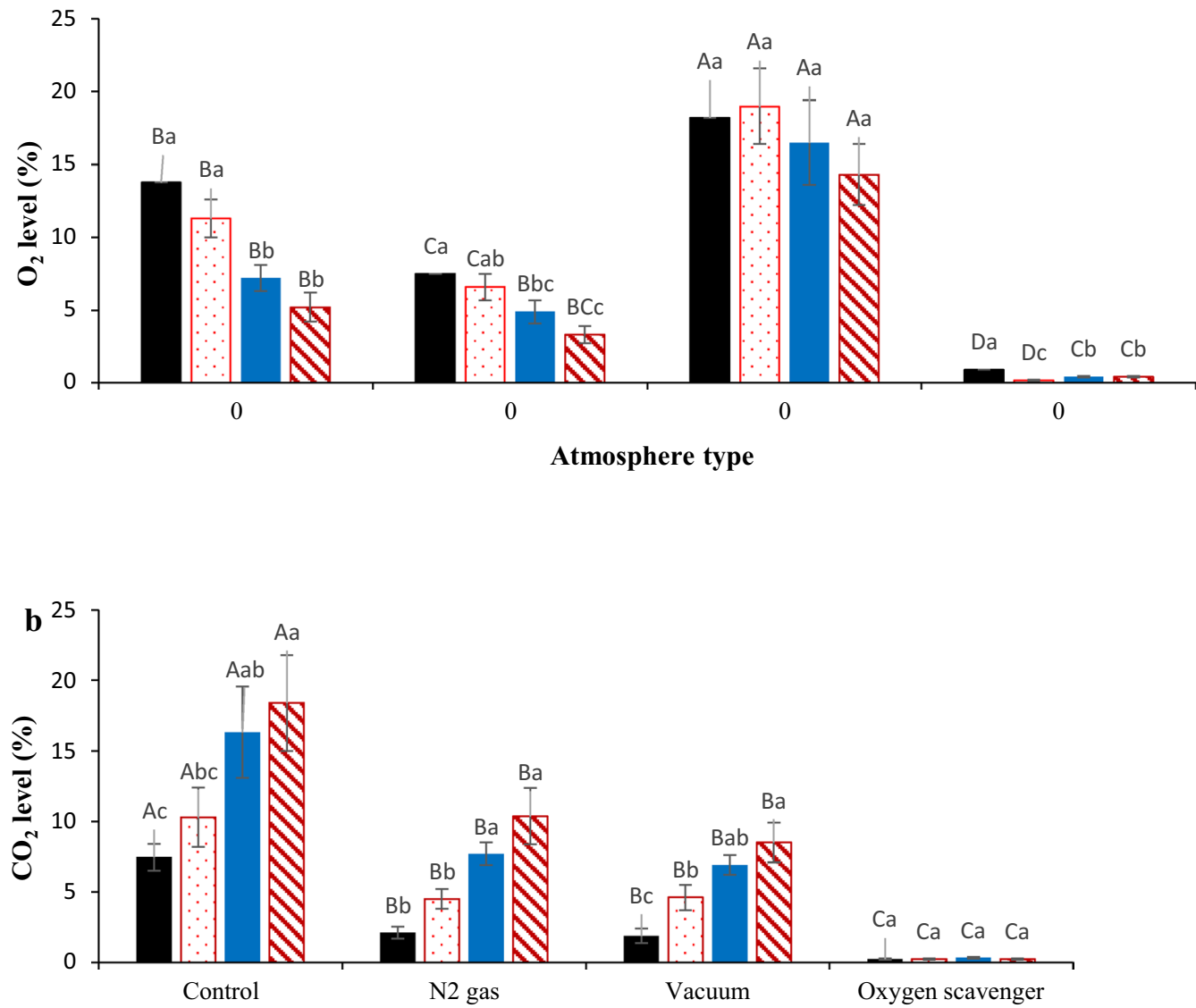

Atmosphere type

Fig. 2 Changes of $\mathbf{a} \mathrm{O}_{2}$ and $\mathbf{b} \mathrm{CO}_{2}$ levels inside the barberry packages under different atmospheres during storage at $25^{\circ} \mathrm{C}$. Error bars show standard deviation (SD). Non-similar uppercase and lowercase letters in each column indicate a significant difference among atmosphere type and storage period, respectively, according to the Tukey test $(P<0.05)$

Table 1 Weight loss* changes (\%) in barberry packages under different atmospheres during storage at 4 and $25^{\circ} \mathrm{C}$

\begin{tabular}{llllll}
\hline Atmosphere type & Temperature & Storage day & & & \\
\cline { 3 - 5 } & & $\mathbf{7}$ & $\mathbf{1 4}$ & $\mathbf{2 1}$ & $\mathbf{2}$ \\
\hline $4^{\circ} \mathrm{C}$ & Control & $0.75 \pm 0.25 \mathrm{Ac}$ & $1.99 \pm 0.09 \mathrm{Ab}$ & $2.41 \pm 0.12 \mathrm{Aa}$ & $2.41 \pm 0.02 \mathrm{Aa}$ \\
& $\mathrm{N}_{2}$ gas & $0.84 \pm 0.02 \mathrm{Ab}$ & $1.27 \pm 0.10 \mathrm{Bab}$ & $1.83 \pm 0.26 \mathrm{Ba}$ & $2.05 \pm 0.61 \mathrm{ABa}$ \\
& Vacuum & $0.81 \pm 0.05 \mathrm{Ac}$ & $0.93 \pm 0.13 \mathrm{Cbc}$ & $1.13 \pm 0.13 \mathrm{Cab}$ & $1.38 \pm 0.10 \mathrm{BCa}$ \\
& Oxygen scavenger & $0.25 \pm 0.03 \mathrm{BC}$ & $0.35 \pm 0.02 \mathrm{Dc}$ & $0.65 \pm 0.02 \mathrm{Db}$ & $0.94 \pm 0.15 \mathrm{Ca}$ \\
$25^{\circ} \mathrm{C}$ & Control & $1.40 \pm 0.29 \mathrm{BC}$ & $4.10 \pm 0.62 \mathrm{ABb}$ & $6.24 \pm 0.78 \mathrm{Aab}$ & $7.64 \pm 1.66 \mathrm{Aa}$ \\
& $\mathrm{N}_{2}$ gas & $2.87 \pm 0.24 \mathrm{Ad}$ & $5.11 \pm 0.60 \mathrm{Ac}$ & $7.06 \pm 0.42 \mathrm{Ab}$ & $8.80 \pm 0.80 \mathrm{Aa}$ \\
& Vacuum & $1.31 \pm 0.29 \mathrm{BC}$ & $3.27 \pm 0.32 \mathrm{Bb}$ & $5.82 \pm 0.90 \mathrm{Aa}$ & $6.79 \pm 0.79 \mathrm{ABa}$ \\
& Oxygen scavenger & $0.79 \pm 0.07 \mathrm{BC}$ & $2.93 \pm 0.55 \mathrm{Bb}$ & $3.03 \pm 0.53 \mathrm{Bb}$ & $4.63 \pm 0.85 \mathrm{Ba}$ \\
\hline
\end{tabular}

* Mean \pm standard deviation (SD)

Non-similar uppercase and lowercase letters indicate a significant difference in columns and rows, respectively, for each temperature according to Tukey test $(P<0.05)$ 
attributed to delayed physiological processes such as respiration and transpiration [25].

\section{Color changes}

The color of a food product is a vital factor that affects its marketability and acceptance among consumers. To measure the color of the barberries inside the packages, the parameters of $L^{*}$ and $a^{*}$ were evaluated, indicating the brightness and redness of the barberry fruits, respectively. The color of the barberries can be affected by the surface wax and anthocyanin content. Surface wax affects the brightness index, such that increased surface wax is accompanied by greater brightness.

The changes of the $\mathrm{L}^{*}$ and $\mathrm{a}^{*}$ parameters of the barberries during storage at 4 and $25^{\circ} \mathrm{C}$ are shown in Table 2 . The results reveal that the effect of atmosphere type on the color parameters of barberries inside the packages during storage at both temperatures was insignificant $(P>0.05)$. According to the results, with longer storage at both temperatures, the values of the $L^{*}$ and $a^{*}$ parameters for barberries packaged under different atmospheres decreased, but these decreases had no statistical significance $(P>0.05)$. This indicates that only a slight decrease occurred in the brightness and redness of the barberries during storage.

After 4 weeks, the $L^{*}$ and $a^{*}$ values were slightly higher for barberries stored at $4{ }^{\circ} \mathrm{C}$ than at $25^{\circ} \mathrm{C}$, indicating a more favorable color. It is noteworthy that the $\mathrm{a}^{*}$ value of barberries decreased significantly during storage, while the inverse occurred for the $L^{*}$ parameter. In other words, it appears that the decrease in a* coincided with an increase in $L^{*}$ for the barberries during storage. These findings are in agreement with the findings of Duan et al.
[28], who revealed that blueberries stored under ambient atmosphere had higher $L^{*}$ and $b *$ indices, but decreased redness $\left(\mathrm{a}^{*}\right)$ relative to those stored under modified atmosphere. The surface color of the product can be affected by the acidity, soluble solids, and anthocyanin content.

We found that following 4 weeks of storage, the highest redness was observed in the $\mathrm{V}$ packages at both temperatures. Candir et al. [23] demonstrated a significant decrease in the $L^{*}$ parameter of pomegranates during 6 months of postharvest storage, but reported that the ones packaged under modified atmosphere remained brighter than the control.

\section{Firmness changes}

The changes in firmness of barberries packaged under the various atmospheres during storage at 4 and $25^{\circ} \mathrm{C}$ are illustrated in Fig. 3. As seen, significant changes occurred in barberry firmness $(P<0.05)$. At both temperatures, with increased storage period, the firmness of the barberries packaged under all atmospheres generally decreased, leading to softer textures. However, this loss in firmness was insignificant in the $\mathrm{V}$ and $O S$ packages, meaning that the texture of the barberries in these packages was preserved better relative to the control.

Radicals generated by aerobic respiration (e.g., superoxide and nitric oxide) weaken the cell wall and make pectin available to pectinase, leading to firmness loss in the postharvest period. Respiration is hindered by the modified atmosphere, stunting the production of radicals. In the presence of minute $\mathrm{O}_{2}$ but high $\mathrm{CO}_{2}$ levels, enzymes involved in tissue softening are activated less, maintaining the firmness of the product. This softening

Table 2 Changes of color parameters ${ }^{*}$ in barberries packaged under different atmospheres during storage at 4 and $25^{\circ} \mathrm{C}$

\begin{tabular}{|c|c|c|c|c|c|c|c|c|}
\hline \multirow{3}{*}{$\begin{array}{l}\text { Atmosphere } \\
\text { type }\end{array}$} & \multirow[t]{3}{*}{ Temperature } & \multicolumn{7}{|l|}{ Storage day } \\
\hline & & \multicolumn{2}{|l|}{7} & \multicolumn{2}{|l|}{14} & \multicolumn{2}{|l|}{21} & 2 \\
\hline & & $a^{*}$ & $L^{*}$ & $a^{*}$ & $L^{*}$ & $a^{*}$ & $L^{*}$ & $a^{*}$ \\
\hline \multicolumn{9}{|c|}{ Harvesting day: $L^{*}=44.8 \pm 3.0 a^{*}=36.1 \pm 2.3$} \\
\hline \multirow[t]{4}{*}{$4{ }^{\circ} \mathrm{C}$} & Control & $26.6 \pm 1.1 \mathrm{ABa}$ & $53.3 \pm 1.7 \mathrm{Aa}$ & $24.2 \pm 1.5 \mathrm{Ba}$ & $52.6 \pm 3.0 \mathrm{Aa}$ & $23.3 \pm 2.7 \mathrm{Aa}$ & $51.0 \pm 0.8 \mathrm{Aa}$ & $27.2 \pm 1.3 \mathrm{Aa} 52.3 \pm 2.0 \mathrm{Aa}$ \\
\hline & $\mathrm{N}_{2}$ gas & $29.1 \pm 0.8 \mathrm{ABa}$ & $52.7 \pm 2.1 \mathrm{Aa}$ & $26.2 \pm 1.9 \mathrm{ABa}$ & $52.6 \pm 2.0 \mathrm{Aa}$ & $26.7 \pm 2.0 \mathrm{Aa}$ & $52.4 \pm 1.6 \mathrm{Aa}$ & $25.8 \pm 3.1 \mathrm{Aa} 51.5 \pm 2.5 \mathrm{Aa}$ \\
\hline & Vacuum & $25.3 \pm 2.4 \mathrm{Ba}$ & $53.0 \pm 2.3 \mathrm{Aa}$ & $26.4 \pm 0.7 \mathrm{ABa}$ & $52.5 \pm 1.4 \mathrm{Aa}$ & $25.9 \pm 2.9 \mathrm{Aa}$ & $51.9 \pm 2.9 \mathrm{Aa}$ & $28.7 \pm 1.9 \mathrm{Aa} 50.8 \pm 1.6 \mathrm{Aa}$ \\
\hline & $\begin{array}{l}\text { Oxygen scaven- } \\
\text { ger }\end{array}$ & $27.5 \pm 0.8 \mathrm{Aa}$ & $53.7 \pm 2.2 \mathrm{Aa}$ & $28.0 \pm 0.8 \mathrm{Aa}$ & $53.3 \pm 3.3 \mathrm{Aa}$ & $26.3 \pm 2.2 \mathrm{Aa}$ & $52.7 \pm 1.9 \mathrm{Aa}$ & $28.3 \pm 2.3 \mathrm{Aa} 51.5 \pm 2.3 \mathrm{Aa}$ \\
\hline \multirow[t]{4}{*}{$25^{\circ} \mathrm{C}$} & Control & $26.4 \pm 0.4 \mathrm{Aa}$ & $54.9 \pm 1.2 \mathrm{Aa}$ & $24.3 \pm 3.1 \mathrm{Aa}$ & $53.3 \pm 1.5 \mathrm{Aa}$ & $20.9 \pm 5.6 \mathrm{Aa}$ & $52.4 \pm 1.6 \mathrm{Aa}$ & $25.8 \pm 3.1 \mathrm{Aa} 51.8 \pm 1.5 \mathrm{Aa}$ \\
\hline & $\mathrm{N}_{2}$ gas & $26.5 \pm 3.0 \mathrm{Aa}$ & $52.9 \pm 0.8 \mathrm{Aa}$ & $26.1 \pm 1.2 \mathrm{Aa}$ & $51.7 \pm 3.2 \mathrm{Aa}$ & $24.7 \pm 0.6 \mathrm{Aa}$ & $51.2 \pm 3.1 \mathrm{Aa}$ & $23.9 \pm 1.5 \mathrm{Aa} 49.8 \pm 1.9 \mathrm{Aa}$ \\
\hline & Vacuum & $28.3 \pm 4.2 \mathrm{Aa}$ & $53.0 \pm 2.0 \mathrm{Aa}$ & $26.0 \pm 3.4 \mathrm{AAa}$ & $52.7 \pm 2.9 \mathrm{Aa}$ & $24.5 \pm 2.2 \mathrm{Aa}$ & $49.8 \pm 4.1 \mathrm{Aa}$ & $27.2 \pm 3.2 \mathrm{Aa} 49.1 \pm 3.1 \mathrm{Aa}$ \\
\hline & $\begin{array}{l}\text { Oxygen scaven- } \\
\text { ger }\end{array}$ & $27.5 \pm 3.5 \mathrm{Aa}$ & $54.2 \pm 2.2 \mathrm{Aa}$ & $26.3 \pm 1.9 a$ & $53.8 \pm 1.0 \mathrm{Aa}$ & $25.9 \pm 2.6 \mathrm{Aa}$ & $54.3 \pm 1.8 \mathrm{Aa}$ & $25.3 \pm 2.3 \mathrm{Aa} 51.1 \pm 3.1 \mathrm{Aa}$ \\
\hline
\end{tabular}

\footnotetext{
* Mean \pm standard deviation (SD)
}

Non-similar uppercase and lowercase letters indicate a significant difference in columns and rows, respectively, for each temperature according to Tukey test $(P<0.05)$ 


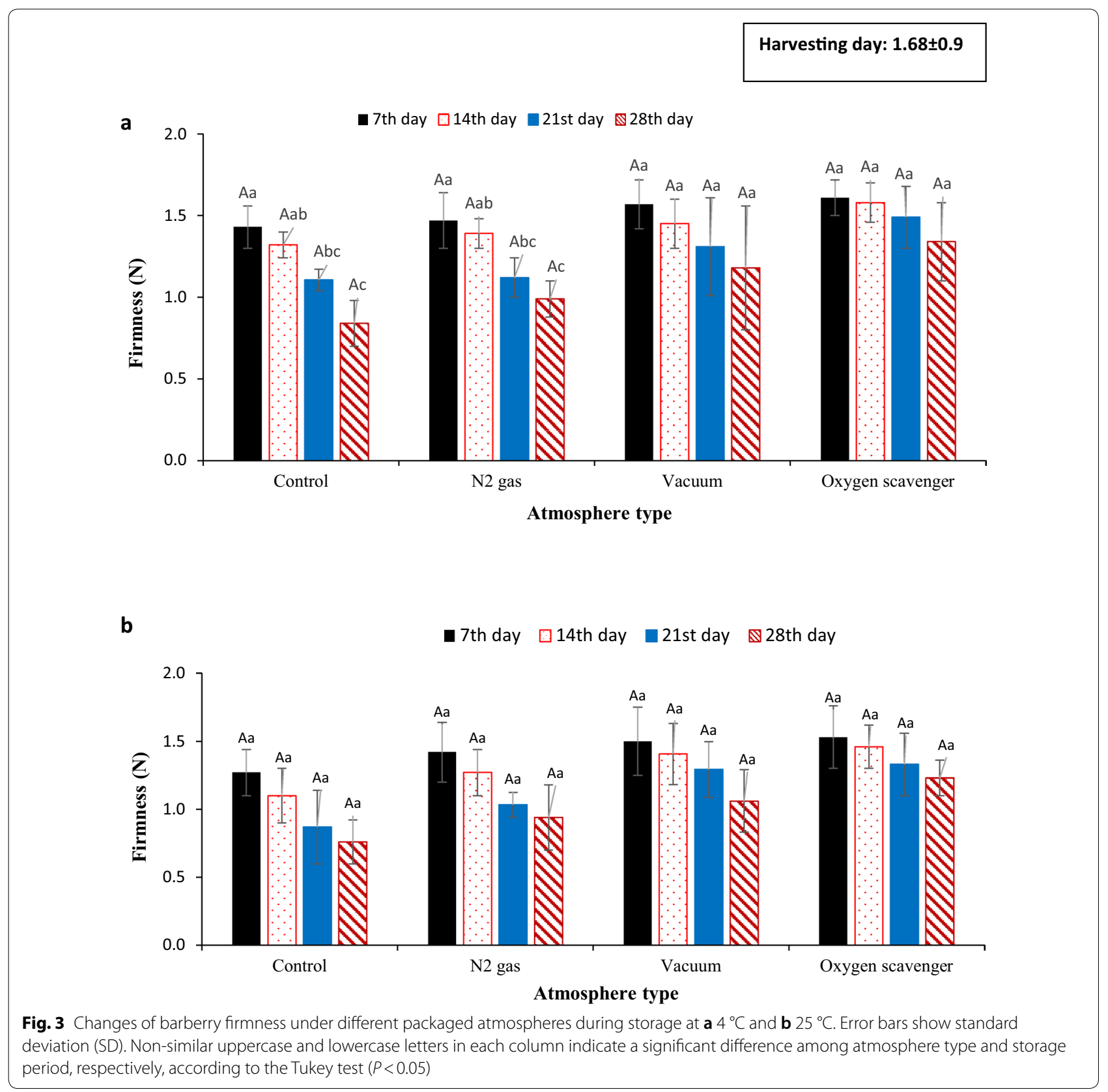

is also reduced by storage at low temperatures, probably as a result of the decreased respiration and perspiration rates, as well as the induction of an inhibitory effect on the hydrolytic enzymes of the cell wall (e.g., polygalacturonase and pectin methyl esterase) and reduced ethylene production [25]. The polygalacturonase enzyme hydrolyzes the $\beta-1-4$ bond of galacturonic acid in the pectin chain, thereby reducing fruit firmness. Mendes et al. [29] described that the firmness of peaches packaged under modified atmosphere decreased.
After 4 weeks of refrigerated storage $\left(4{ }^{\circ} \mathrm{C}\right)$, the highest firmness was observed in the OS and V packages, which exhibited 20.2 and $29.8 \%$ more firmness relative to the harvesting day, respectively, and 59.5 and $40.5 \%$ more firmness compared with the control on the same day $\left(28^{\text {th }}\right.$ day), respectively. The same trend was observed at the temperature of $25{ }^{\circ} \mathrm{C}$. The effect of storage atmosphere on firmness varies depending on packaging conditions and temperature. Vicente et al. [30] argued that tissue firmness or softness largely depends on hemi-cellulose 
depolymerization, while Fava et al. [31] stated that flexibility or swelling depends on the regulation of internal turgor pressure mostly by cuticular wax, which is as an excellent barrier to excessive water loss. Firmness changes during storage also depend on the amount of water condensed at the surface of the product and water loss. Changes in tissue characteristics due to water loss are directly related to decreased turgor pressure, which may be associated with external periderm resistance or periderm removal for water vapor transfer [32].

\section{Titratable acidity changes}

The changes in the titratable acidity of barberry samples stored at 4 and $25{ }^{\circ} \mathrm{C}$ are exhibited in Tables 3 and 4 , respectively. The results show that in the control sample, the acidity changes did not follow a certain trend, with the only significant decrease being identified after 28 days $(P<0.05)$. No significant change was observed in the acidity of the OS and $\mathrm{N}$ samples over the storage period $(P>0.05)$. Following 4 weeks of storage, the OS sample had the maximum acidity and the least change in this parameter relative to the harvesting day. It is worth noting that the acidity in the OS and V samples initially increased during the first 7 days of storage, but then gradually decreased. Respiration has been reported as the most important factor that can convert sugars into energy in the presence of $\mathrm{O}_{2}$, meaning that the fall in acidity after the initial rise could be related to the increase in $\mathrm{O}_{2}$ concentration [32].
In barberries packaged under $\mathrm{C}$ and $\mathrm{N}$ atmospheres at $25^{\circ} \mathrm{C}$, the acidity gradually decreased until the $7^{\text {th }}$ day of storage, before slightly increasing by day 14 , then gradually decreasing again until the end of storage. Of course, it is important to note that these changes were not significant in most cases $(P>0.05)$. Generally, after 4 weeks, the lowest acidity was observed in sample C. After harvest and during storage, organic acids are converted to starch or sugar, leading to decreased titratable acidity [28]. Notably, changes in acidity can also affect the fruit taste.

\section{Anthocyanin content changes}

Barberry is a rich source of anthocyanins. Lack of oxygen, low $\mathrm{pH}$, and low processing or storage temperature are the most important conditions that increase anthocyanin stability. So far, numerous studies have focused on the influence of temperature, processing, and storage duration on the stability of anthocyanins, but no definitive results have been obtained.

The content of anthocyanins in barberries packaged for 4 weeks under different atmospheres at 4 and $25{ }^{\circ} \mathrm{C}$ is portrayed in Tables 3 and 4, respectively. The results show that the effect of atmosphere type on anthocyanin content was significant at both temperatures $(P<0.05)$. At $4{ }^{\circ} \mathrm{C}$, the anthocyanin content of the barberries in the control sample slightly increased during the first week of storage. Generally, with lengthened storage time, a decreasing trend was seen for anthocyanin content across

Table 3 Changes* of titratable acidity, anthocyanin and ascorbic acid contents in barberries packaged under different atmospheres during storage at $4^{\circ} \mathrm{C}$

\begin{tabular}{|c|c|c|c|c|c|}
\hline \multirow[t]{2}{*}{ Characteristics } & \multirow[t]{2}{*}{ Atmosphere type } & \multicolumn{4}{|l|}{ Storage day } \\
\hline & & 7 & 14 & 21 & 28 \\
\hline \multicolumn{6}{|l|}{ Harvesting day $=4.7 \pm 0.13$} \\
\hline \multirow[t]{4}{*}{ Acidity (\%) } & Control & $4.08 \pm 0.42 \mathrm{Ba}$ & $3.51 \pm 0.17 \mathrm{Bab}$ & $3.89 \pm 0.12 \mathrm{Ba}$ & $3.24 \pm 0.10 \mathrm{Cb}$ \\
\hline & $\mathrm{N}_{2}$ gas & $3.73 \pm 0.08 \mathrm{Ba}$ & $3.96 \pm 0.20 \mathrm{Ba}$ & $3.89 \pm 0.21 \mathrm{Ba}$ & $3.84 \pm 0.17 \mathrm{Ba}$ \\
\hline & Vacuum & $4.89 \pm 0.18 \mathrm{Aa}$ & $4.69 \pm 0.29 A a b$ & $4.55 \pm 0.23 \mathrm{Aab}$ & $4.20 \pm 0.28 \mathrm{Ab}$ \\
\hline & Oxygen scavenger & $4.89 \pm 0.25 \mathrm{Aa}$ & $4.70 \pm 0.19 \mathrm{Aa}$ & $4.73 \pm 0.27 \mathrm{Aa}$ & $4.52 \pm 0.17 \mathrm{Aa}$ \\
\hline \multicolumn{6}{|c|}{ Harvesting day $=659.3 \pm 6.3$} \\
\hline \multirow[t]{4}{*}{ Anthocyanin (mg/100 g) } & Control & $688.4 \pm 1.3 \mathrm{Aa}$ & $622.6 \pm 11.5 \mathrm{Ab}$ & $611.0 \pm 3.6 \mathrm{Ab}$ & $548.4 \pm 3.6 C c$ \\
\hline & $\mathrm{N}_{2}$ gas & $585.0 \pm 2.3 \mathrm{Cb}$ & $626.7 \pm 22.6 \mathrm{Aa}$ & $616.3 \pm 9.4 \mathrm{Aab}$ & $584.6 \pm 15.2 \mathrm{Bb}$ \\
\hline & Vacuum & $599.3 \pm 2.7 \mathrm{Ba}$ & $596.4 \pm 3.6 \mathrm{Aa}$ & $535.5 \pm 30.1 \mathrm{Bb}$ & $497.7 \pm 7.1 \mathrm{Db}$ \\
\hline & Oxygen scavenger & $607.6 \pm 5.9 \mathrm{BC}$ & $686.3 \pm 10.7 \mathrm{Aa}$ & $647.3 \pm 3.6 \mathrm{Ab}$ & $632.7 \pm 12.3 \mathrm{Ab}$ \\
\hline \multicolumn{6}{|l|}{ Harvesting day $=7.28 \pm 0.38$} \\
\hline \multirow[t]{4}{*}{ Ascorbic acid (mg/100 g) } & Control & $5.87 \pm 1.20 \mathrm{Aa}$ & $4.94 \pm 0.31 \mathrm{Bab}$ & $4.09 \pm 0.17 \mathrm{Cb}$ & $3.74 \pm 0.26 \mathrm{Bb}$ \\
\hline & $\mathrm{N}_{2}$ gas & $5.62 \pm 0.59 \mathrm{Aa}$ & $5.00 \pm 0.18 \mathrm{Bab}$ & $4.67 \pm 0.33 \mathrm{BCbc}$ & $4.01 \pm 0.12 \mathrm{BC}$ \\
\hline & Vacuum & $6.19 \pm 0.31 \mathrm{Aa}$ & $5.56 \pm 0.35 \mathrm{ABab}$ & $4.94 \pm 0.25 \mathrm{Bbc}$ & $4.29 \pm 0.32 B C$ \\
\hline & Oxygen scavenger & $6.85 \pm 0.50 \mathrm{Aa}$ & $6.24 \pm 0.38 \mathrm{Aab}$ & $5.83 \pm 0.28 \mathrm{Ab}$ & $5.37 \pm 0.34 \mathrm{Ab}$ \\
\hline
\end{tabular}

* Mean \pm standard deviation (SD)

Non-similar uppercase and lowercase letters indicate a significant difference in columns and rows, respectively, for each temperature according to Tukey test $(P<0.05)$ 
Table 4 Changes* of titratable acidity, anthocyanin and ascorbic acid contents in barberries packaged under different atmospheres during storage at $25^{\circ} \mathrm{C}$

\begin{tabular}{|c|c|c|c|c|c|}
\hline \multirow[t]{2}{*}{ Characteristics } & \multirow[t]{2}{*}{ Atmosphere type } & \multicolumn{4}{|l|}{ Storage day } \\
\hline & & 7 & 14 & 21 & 28 \\
\hline \multicolumn{6}{|l|}{ Harvesting day $=4.7 \pm 0.13$} \\
\hline \multirow[t]{4}{*}{ Acidity (\%) } & Control & $3.48 \pm 0.20 \mathrm{Bab}$ & $3.86 \pm 0.14 \mathrm{Aa}$ & $3.51 \pm 0.17 \mathrm{Bab}$ & $3.15 \pm 0.13 \mathrm{Ab}$ \\
\hline & $\mathrm{N}_{2}$ gas & $3.69 \pm 0.34 \mathrm{Bab}$ & $3.95 \pm 0.07 \mathrm{Aa}$ & $3.53 \pm 0.07 \mathrm{Ba}$ & $3.46 \pm 0.07 \mathrm{Aa}$ \\
\hline & Vacuum & $4.42 \pm 0.20 \mathrm{Aa}$ & $4.16 \pm 0.46 \mathrm{Aa}$ & $3.87 \pm 0.46 \mathrm{Aa}$ & $3.79 \pm 0.70 \mathrm{Aa}$ \\
\hline & Oxygen scavenger & $4.56 \pm 0.05 \mathrm{Aa}$ & $4.33 \pm 0.04 \mathrm{Aa}$ & $3.94 \pm 0.04 \mathrm{Aa}$ & $3.85 \pm 0.75 \mathrm{Aa}$ \\
\hline \multicolumn{6}{|l|}{ Harvesting day $=659.3 \pm 6.3$} \\
\hline \multirow[t]{4}{*}{ Anthocyanin (mg/100 g) } & Control & $593.8 \pm 25.9 \mathrm{BCa}$ & $535.7 \pm 23.1 \mathrm{Bab}$ & $591.7 \pm 22.4 \mathrm{ABa}$ & $515.9 \pm 34.7 \mathrm{Bb}$ \\
\hline & $\mathrm{N}_{2}$ gas & $557.2 \pm 19.5 \mathrm{Cb}$ & $647.3 \pm 33.7 \mathrm{Aa}$ & $537.0 \pm 31.2 \mathrm{Bb}$ & $585.1 \pm 35.0 \mathrm{ABab}$ \\
\hline & Vacuum & $645.5 \pm 6.6 \mathrm{Aab}$ & $686.6 \pm 40.2 \mathrm{Aa}$ & $616.2 \pm 25.7 \mathrm{Ab}$ & $592.8 \pm 22.2 \mathrm{ABb}$ \\
\hline & Oxygen scavenger & $624.8 \pm 11.4 \mathrm{ABa}$ & $672.4 \pm 32.3 \mathrm{Aa}$ & $635.2 \pm 30.7 \mathrm{Aa}$ & $608.9 \pm 39.0 \mathrm{Aa}$ \\
\hline \multicolumn{6}{|l|}{ Harvesting day $=7.28 \pm 0.38$} \\
\hline \multirow[t]{4}{*}{ Ascorbic acid (mg/100 g) } & Control & $5.67 \pm 0.62 \mathrm{Aa}$ & $3.35 \pm 0.66 \mathrm{Bb}$ & $2.43 \pm 0.58 \mathrm{Bb}$ & $2.32 \pm 0.42 \mathrm{Bb}$ \\
\hline & $\mathrm{N}_{2}$ gas & $6.54 \pm 0.84 \mathrm{Aa}$ & $5.43 \pm 0.90 \mathrm{ABab}$ & $5.09 \pm 0.91 \mathrm{Aab}$ & $3.86 \pm 0.59 \mathrm{ABb}$ \\
\hline & Vacuum & $6.41 \pm 0.41 \mathrm{Aa}$ & $5.96 \pm 0.86 \mathrm{Aab}$ & $5.19 \pm 0.60 \mathrm{Aab}$ & $4.18 \pm 1.00 \mathrm{ABb}$ \\
\hline & Oxygen scavenger & $6.48 \pm 0.81 \mathrm{Aa}$ & $6.11 \pm 0.81 \mathrm{Aa}$ & $5.56 \pm 0.67 \mathrm{Aa}$ & $4.65 \pm 1.10 \mathrm{Aa}$ \\
\hline
\end{tabular}

Non-similar uppercase and lowercase letters indicate a significant difference in columns and rows, respectively, for each temperature according to Tukey test $(P<0.05)$

all packages and at both temperatures, which is consistent with the results of Dhinesh Kumar et al. [33]. However, the anthocyanin content in the $\mathrm{N}$ and OS packages increased significantly after 14 days of storage at $4{ }^{\circ} \mathrm{C}$, but followed the same decreasing trend thereafter. Similarly, initial rises in anthocyanin content were seen in the $C$, $\mathrm{N}, \mathrm{V}$, and $\mathrm{OS}$ packages stored at $25^{\circ} \mathrm{C}$, but these changes were not statistically significant $(P<0.05)$. Correspondingly, Candir et al. [23] demonstrated that the anthocyanin content of pomegranates increased during the first 2 months of storage at $6{ }^{\circ} \mathrm{C}$, but decreased thereafter until the $6^{\text {th }}$ month. These researchers also reported that pomegranates stored under modified atmosphere packages had lower anthocyanin contents relative to the control.

The stability of anthocyanins is affected by their chemical nature, process temperatures, storage conditions, postharvesting operations, proximity to light and metals, and $\mathrm{pH}$. Oxidative enzymes may be responsible for falls in anthocyanin content during storage. However, the synthesis of anthocyanins at low temperatures has also been reported. In addition, the synthesis or breakdown of anthocyanins is affected by the amounts of $\mathrm{O}_{2}$ and $\mathrm{CO}_{2}$ present [33].

After 4 weeks of storage, the highest anthocyanin content was observed in the OS sample, which had 15.4 and $18 \%$ more anthocyanins relative to the $C$ sample stored at 4 and $25{ }^{\circ} \mathrm{C}$, respectively. Decreasing the availability of $\mathrm{O}_{2}$ and thus increasing the $\mathrm{CO}_{2}$ level reduces the biosynthesis of anthocyanins [32]. It has been reported that modified atmospheres can prevent the biosynthesis of anthocyanins [24].

In general, the results of this study confirm that with increasing temperature, the rate of anthocyanin degradation is augmented, which can be correlated with a reduction in acidity as well as an increase in weight loss [26].

\section{Ascorbic acid content changes}

The results show that with the prolongation of the storage period, the ascorbic acid content in the barberries stored at both temperatures decreased (Tables 3 and 4), which is in agreement with the findings of Wani et al. [27]. Decreased ascorbic acid content may be related to a deficiency in its biosynthesis or its rapid decomposition under modified atmospheric conditions. It can also be ascribed to water loss, cell wall damage, and increased environmental temperature and humidity. Given that the compound has high sensitivity to the phenolase enzyme, temperature, light, oxygen, and $\mathrm{pH}$ [33], such reductions in ascorbic acid content during storage were expected.

A quick look at Tables 3 and 4 reveals that the atmosphere of the $\mathrm{N}, \mathrm{V}$, and OS packages more efficiently maintained the ascorbic acid content. Following 4 weeks of refrigerated storage $\left(4{ }^{\circ} \mathrm{C}\right)$, the OS sample had the maximum level of ascorbic acid at $5.4 \mathrm{mg} / 100 \mathrm{~g}$, which was $45.9 \%$ higher than the control. Modified atmospheres can reduce the oxidation of ascorbic acid to dehydroascorbic acid and thus help maintain it. The amount of ascorbic acid is also affected by genotypic differences, pre-harvest 
climate conditions, and management methods during and after harvesting [25].

A similar result was observed at the higher temperature $\left(25^{\circ} \mathrm{C}\right)$, with barberries in the OS packages retaining the highest content of ascorbic acid (approximately twice that of the $C$ samples) after 4 weeks of storage.

\section{Changes in total phenolic compounds}

Phenolic compounds are vital for cell and tissue protection as they act as direct antioxidants. The TPC content of barberries in the different packages over 4 weeks at 4 and $25^{\circ} \mathrm{C}$ is given in Tables 5 and 6 , respectively. The evaluation of changes in the $C$ packages at both temperatures showed a decrease in TPC with increased storage time. This decrease was less initially at $25^{\circ} \mathrm{C}$ than at $4{ }^{\circ} \mathrm{C}$, but intensified toward the end of the 4 weeks; the final TPC content of the $C$ sample was slightly higher at $4{ }^{\circ} \mathrm{C}$ than at $25^{\circ} \mathrm{C}$. The same was true for the other packages.

The amount of phenolic compounds is affected by genetics and the environment. Nonetheless, this content can also be affected by oxidization reactions that take place at the time of processing or storage, with stress conditions inducing a rise in TPC. The response to wound stress (stress of phytochemicals reducing) during minimal process operations is a well-known phenomenon. Generally, the process of oxidative regulation strengthens the system's dynamic balance by producing or inhibiting species of active oxygen. Firstly, the tissue responds to stress, leading to the production of active oxygen species and activating the systems responsible for producing antioxidant compounds. If the stress level is high, the tissue may not be able to maintain the necessary balance, and the cells become damaged [29]. An increased TPC amount during refrigerated storage can also be related to the stimulation of enzymes involved in their biosynthesis during cold storage conditions [33].

The minimum changes in TPC at both temperatures were related to the OS packages, such that after four weeks, the TPC content was 32.7 and $23.2 \%$ higher than the $\mathrm{C}$ packages at 4 and $25^{\circ} \mathrm{C}$, respectively, decreasing by 8.1 and $17.2 \%$ relative to the harvesting day, respectively. The vacuum and nitrogen atmospheres were also able to retain the phenolic compounds well. It has been reported that the reduction of TPC during storage can be related to the decomposition of these compounds secondary to enzymatic activity, water loss, and changes in acidity and total soluble solids [33].

For the barberries stored at $25^{\circ} \mathrm{C}$, significant changes in TPC content were not observed after four weeks among the different packaging atmospheres $(P>0.05)$. Pinela et al. [1] stated that TPC content of green cress packaged under argon gas or natural atmosphere remained at its original level, while slight reductions were observed in those packaged under vacuum and nitrogen.

\section{Antioxidant activity changes}

Antioxidant activity was measured through the DPPH and FRAP methods. Tables 5 and 6 show the $\mathrm{RSC}_{\mathrm{DPPH}}$

Table 5 Changes* of total phenolic compounds and antioxidant activity in barberries packaged under different atmospheres during storage at $4^{\circ} \mathrm{C}$

\begin{tabular}{|c|c|c|c|c|c|}
\hline \multirow[t]{2}{*}{ Characteristics } & \multirow[t]{2}{*}{ Atmosphere type } & \multicolumn{4}{|l|}{ Storage day } \\
\hline & & 7 & 14 & 21 & 28 \\
\hline \multicolumn{6}{|c|}{ Harvesting day $=197.1 \pm 4.4$} \\
\hline \multirow{4}{*}{$\begin{array}{l}\text { Phenolic compounds } \\
\text { (mg/100 g) }\end{array}$} & Control & $162.8 \pm 2.1 \mathrm{Ba}$ & $156.1 \pm 1.4 \mathrm{Ca}$ & $143.9 \pm 1.9 \mathrm{Ba}$ & $136.5 \pm 11.0 \mathrm{Ba}$ \\
\hline & $\mathrm{N}_{2}$ gas & $151.3 \pm 4.5 \mathrm{Ca}$ & $159.7 \pm 2.9 \mathrm{BCa}$ & $148.2 \pm 1.1 \mathrm{Ba}$ & $145.1 \pm 14.9 \mathrm{Ba}$ \\
\hline & Vacuum & $158.6 \pm 3.6 \mathrm{BCa}$ & $167.3 \pm 2.7 \mathrm{Ba}$ & $159.1 \pm 11.1 \mathrm{Ba}$ & $152.1 \pm 11.9 \mathrm{ABa}$ \\
\hline & Oxygen scavenger & $191.6 \pm 2.7 \mathrm{Aa}$ & $186.6 \pm 6.2 \mathrm{Aa}$ & $190.4 \pm 0.5 \mathrm{Aa}$ & $181.2 \pm 10.8 \mathrm{Aa}$ \\
\hline \multicolumn{6}{|c|}{ Harvesting day $=72.9 \pm 2.3$} \\
\hline \multirow[t]{4}{*}{$\mathrm{RSC}_{\mathrm{DPPH}}(\%)$} & Control & $63.6 \pm 6.7 \mathrm{ABa}$ & $59.0 \pm 3.7 \mathrm{Bab}$ & $54.9 \pm 3.6 \mathrm{Abc}$ & $50.3 \pm 3.0 \mathrm{BC}$ \\
\hline & $\mathrm{N}_{2}$ gas & $67.1 \pm 2.9 \mathrm{Aa}$ & $66.3 \pm 3.6 \mathrm{Aa}$ & $51.2 \pm 2.7 \mathrm{Bb}$ & $49.8 \pm 2.9 \mathrm{Bb}$ \\
\hline & Vacuum & $57.1 \pm 3.8 \mathrm{Ba}$ & $55.0 \pm 4.1 \mathrm{Ba}$ & $54.2 \pm 2.8 \mathrm{Aa}$ & $48.7 \pm 3.1 \mathrm{Bb}$ \\
\hline & Oxygen scavenger & $60.3 \pm 5.7 \mathrm{ABa}$ & $58.6 \pm 2.9 \mathrm{Ba}$ & $56.4 \pm 3.0 \mathrm{Aa}$ & $59.2 \pm 4.0 \mathrm{Aa}$ \\
\hline \multicolumn{6}{|c|}{ Harvesting day $=99.4 \pm 4.1$} \\
\hline \multirow[t]{4}{*}{$\operatorname{FRAP}(\mathrm{mmol} / \mathrm{L})$} & Control & $71.4 \pm 4.6 \mathrm{Ba}$ & $68.8 \pm 5.1 \mathrm{Bab}$ & $62.2 \pm 3.8 \mathrm{Bb}$ & $65.2 \pm 8.3 \mathrm{Bab}$ \\
\hline & $\mathrm{N}_{2}$ gas & $71.1 \pm 3.6 \mathrm{Bab}$ & $73.3 \pm 3.8 \mathrm{Aa}$ & $71.7 \pm 3.5 \mathrm{Aab}$ & $69.3 \pm 5.0 \mathrm{ABb}$ \\
\hline & Vacuum & $75.3 \pm 4.1 \mathrm{Aa}$ & $76.0 \pm 3.4 \mathrm{Aa}$ & $73.4 \pm 6.0 \mathrm{Aa}$ & $71.9 \pm 4.1 \mathrm{ABa}$ \\
\hline & Oxygen scavenger & $71.5 \pm 4.6 \mathrm{Ba}$ & $72.6 \pm 4.7 \mathrm{Aa}$ & $75.2 \pm 5.4 \mathrm{Aa}$ & $76.3 \pm 7.2 \mathrm{Aa}$ \\
\hline
\end{tabular}

* Mean \pm standard deviation (SD)

Non-similar uppercase and lowercase letters indicate a significant difference in columns and rows, respectively, for each temperature according to Tukey test $(P<0.05)$ 
Table 6 Changes $^{*}$ of total phenolic compounds and antioxidant activity in barberries packaged under different atmospheres during storage at $25^{\circ} \mathrm{C}$

\begin{tabular}{|c|c|c|c|c|c|}
\hline \multirow[t]{2}{*}{ Characteristics } & \multirow[t]{2}{*}{ Atmosphere type } & \multicolumn{4}{|l|}{ Storage day } \\
\hline & & 7 & 14 & 21 & 28 \\
\hline \multicolumn{6}{|c|}{ Harvesting day $=197.1 \pm 4.4$} \\
\hline \multirow{4}{*}{$\begin{array}{l}\text { Phenolic compounds } \\
\text { (mg/100 g) }\end{array}$} & Control & $175.1 \pm 2.7 \mathrm{Ca}$ & $176.3 \pm 2.6 \mathrm{Aa}$ & $148.6 \pm 3.1 \mathrm{Ab}$ & $132.5 \pm 6.1 \mathrm{Ac}$ \\
\hline & $\mathrm{N}_{2}$ gas & $194.3 \pm 3.9 \mathrm{Ba}$ & $164.0 \pm 2.5 \mathrm{Bb}$ & $159.0 \pm 1.9 \mathrm{Ab}$ & $154.2 \pm 14.2 \mathrm{Ab}$ \\
\hline & Vacuum & $219.6 \pm 3.2 \mathrm{Aa}$ & $177.0 \pm 3.6 \mathrm{Ab}$ & $167.4 \pm 17.0 \mathrm{Ab}$ & $160.2 \pm 15.2 \mathrm{Ab}$ \\
\hline & Oxygen scavenger & $180.2 \pm 5.2 \mathrm{Ca}$ & $181.4 \pm 1.7 \mathrm{Aa}$ & $171.4 \pm 3.7 \mathrm{Aa}$ & $163.3 \pm 13.3 \mathrm{Aa}$ \\
\hline \multicolumn{6}{|c|}{ Harvesting day $=72.9 \pm 2.3$} \\
\hline \multirow[t]{4}{*}{$\mathrm{RSC}_{\mathrm{DPPH}}(\%)$} & Control & $61.0 \pm 5.5 \mathrm{Aa}$ & $53.5 \pm 6.0 \mathrm{Aab}$ & $47.3 \pm 4.5 \mathrm{Aab}$ & $47.3 \pm 4.5 \mathrm{Aab}$ \\
\hline & $\mathrm{N}_{2}$ gas & $64.2 \pm 4.1 \mathrm{Aa}$ & $59.2 \pm 6.4 \mathrm{Aab}$ & $51.5 \pm 5.5 \mathrm{Aab}$ & $51.5 \pm 5.5 \mathrm{Aab}$ \\
\hline & Vacuum & $65.9 \pm 6.4 \mathrm{Aa}$ & $53.1 \pm 7.8 \mathrm{Aab}$ & $48.2 \pm 3.3 \mathrm{Ab}$ & $48.2 \pm 3.3 \mathrm{Ab}$ \\
\hline & Oxygen scavenger & $59.8 \pm 6.4 \mathrm{Aa}$ & $59.3 \pm 4.4 \mathrm{Aa}$ & $52.6 \pm 8.9 \mathrm{Aa}$ & $52.6 \pm 8.9 \mathrm{Aa}$ \\
\hline \multicolumn{6}{|c|}{ Harvesting day $=99.4 \pm 4.1$} \\
\hline \multirow[t]{4}{*}{ FRAP (mmol/L) } & Control & $68.8 \pm 2.0 \mathrm{Aab}$ & $78.8 \pm 10.1 \mathrm{Aa}$ & $66.2 \pm 7.8 \mathrm{Aab}$ & $55.4 \pm 9.9 \mathrm{Ab}$ \\
\hline & $\mathrm{N}_{2}$ gas & $75.5 \pm 9.2 \mathrm{Aa}$ & $84.9 \pm 10.3 \mathrm{Aa}$ & $71.4 \pm 6.5 \mathrm{Aa}$ & $62.4 \pm 12.3 \mathrm{Aa}$ \\
\hline & Vacuum & $74.3 \pm 9.5 \mathrm{Aa}$ & $72.8 \pm 8.7 \mathrm{Aa}$ & $69.7 \pm 15.2 \mathrm{Aa}$ & $62.1 \pm 3.0 \mathrm{Aa}$ \\
\hline & Oxygen scavenger & $75.8 \pm 3.6 \mathrm{Aa}$ & $78.7 \pm 9.6 \mathrm{Aa}$ & $70.4 \pm 11.4 \mathrm{Aa}$ & $72.5 \pm 10.5 \mathrm{Aa}$ \\
\hline
\end{tabular}

* Mean \pm standard deviation (SD)

Non-similar uppercase and lowercase letters indicate a significant difference in columns and rows, respectively, for each temperature according to Tukey test $(P<0.05)$

and FRAP results for the barberries stored for four weeks under different packaged atmospheres at 4 and $25{ }^{\circ} \mathrm{C}$, respectively. The initial shock after harvest was marked by a significant reduction in the antioxidant activity of barberries in the $\mathrm{C}$ packages, and the declining trend continued for the barberries packaged under all atmospheres. The $\mathrm{RSC}_{\mathrm{DPPH}}$ of barberries stored under natural atmosphere (package $\mathrm{C}$ ) at $4{ }^{\circ} \mathrm{C}$ decreased by $9.3,13.9,18$, and $22.6 \%$, in the first, second, third, and fourth weeks, respectively, while the corresponding decreases at $25{ }^{\circ} \mathrm{C}$ were $11.9,19.4,25.6$ and $29.6 \%$, respectively.

The reduction of antioxidant activity may also be attributed to the acceleration of TPC oxidation in the presence of oxygen. The presence of the OS was able to maintain the $\mathrm{RSC}_{\mathrm{DPPH}}$ over the four weeks by 86.3 and $78.1 \%$ at 4 and $25{ }^{\circ} \mathrm{C}$, respectively. The decomposition of color compounds and product aging may also be responsible for the drop in antioxidant activity [25].

The FRAP of barberries packaged under the natural atmosphere (sample $\mathrm{C}$ ) at $4{ }^{\circ} \mathrm{C}$ decreased by $28.2,30.8$, 37.4 , and $34.4 \%$ during weeks $1,2,3$, and 4 , respectively, while the corresponding decreases at $25{ }^{\circ} \mathrm{C}$ were 30.8 , $20.7,33.4$ and $44.3 \%$, respectively. The presence of the OS maintained the reducing power of iron in the barberries and thus FRAP did not show significant changes in these packages during storage at both temperatures. At the end of the $28^{\text {th }}$ day, the FRAP of the barberries inside the OS packages stored at 4 and $25{ }^{\circ} \mathrm{C}$ increased by 23.2 and $27.1 \%$ relative to the harvesting day, respectively, while the corresponding increases were by 17 and $30.9 \%$ in the $C$ packages, respectively.

After 4 weeks of storage at both temperatures, the $\mathrm{RSC}_{\mathrm{DPPH}}$ and FRAP of the barberries did not differ significantly between the $\mathrm{V}, \mathrm{N}$, and $\mathrm{C}$ packages $(P>0.05)$.

\section{Decay incidence}

Fungal decay was evaluated based on visual observations of molds. The results revealed that the atmosphere inside the packages clearly had a significant effect on fungal decay incidence (Table 7) during storage at 4 and $25^{\circ} \mathrm{C}$. As the storage period lengthened, increased fungal decay was seen in all packages other than the OS samples. Further, the rate of decay incidence was higher at $25^{\circ} \mathrm{C}$ than at $4{ }^{\circ} \mathrm{C}$, which is consistent with the results of Wani et al. [27].

Changing the atmosphere inside the packages during storage activates the fruit's defensive responses and increases disease resistance. When respiration decreases due to limited $\mathrm{O}_{2}$ availability, a negative response may be observed to changes in the packaging atmosphere. Lower $\mathrm{O}_{2}$ concentrations often cause fermentation. Furthermore, increasing the storage temperature elevated the rate of decay incidence. The condensation of water vapor inside the package can also facilitate further growth of microorganisms [32].

As shown in Table 7, barberries packaged in the presence of the OS did not undergo fungal decay during the storage period at both studied temperatures (except 
Table 7 Decay incidence (\%) ${ }^{*}$ in barberry packages during storage at $4{ }^{\circ} \mathrm{C}$ and $25^{\circ} \mathrm{C}$

\begin{tabular}{|c|c|c|c|c|c|}
\hline \multirow[t]{2}{*}{ Atmosphere type } & \multirow[t]{2}{*}{ Temperature } & \multicolumn{4}{|l|}{ Storage day } \\
\hline & & 7 & 14 & 21 & 28 \\
\hline \multirow[t]{4}{*}{$4^{\circ} \mathrm{C}$} & Control & $2.0 \pm 1.0 \mathrm{AC}$ & $2.3 \pm 1.5 \mathrm{ABC}$ & $20.7 \pm 4.0 \mathrm{Ab}$ & $29.0 \pm 3.6 \mathrm{Aa}$ \\
\hline & $\mathrm{N}_{2}$ gas & $0.0 \pm 0.0 \mathrm{Bb}$ & $5.0 \pm 3.0 \mathrm{Ab}$ & $26.3 \pm 5.5 \mathrm{Aa}$ & $34.7 \pm 4.5 \mathrm{Aa}$ \\
\hline & Vacuum & $0.0 \pm 0.0 \mathrm{Bb}$ & $0.0 \pm 0.0 \mathrm{Bb}$ & $0.7 \pm 1.2 \mathrm{Bb}$ & $10.3 \pm 3.5 \mathrm{Ba}$ \\
\hline & Oxygen scavenger & $0.0 \pm 0.0 \mathrm{Ba}$ & $0.0 \pm 0.0 \mathrm{Ba}$ & $0.0 \pm 0.0 \mathrm{Ba}$ & $0.0 \pm 0.0 \mathrm{Ca}$ \\
\hline \multirow[t]{4}{*}{$25^{\circ} \mathrm{C}$} & Control & $8.3 \pm 1.5 \mathrm{Ac}$ & $27.3 \pm 2.5 \mathrm{Ab}$ & $32.0 \pm 4.6 \mathrm{Aab}$ & $37.0 \pm 3.0 \mathrm{Aa}$ \\
\hline & $\mathrm{N}_{2}$ gas & $5.0 \pm 2.0 \mathrm{BC}$ & $20.0 \pm 3.6 \mathrm{Bb}$ & $28.0 \pm 3.6 \mathrm{Aa}$ & $32.0 \pm 2.6 \mathrm{Aa}$ \\
\hline & Vacuum & $0.0 \pm 0.0 \mathrm{Cc}$ & $3.3 \pm 1.2 \mathrm{Cc}$ & $10.3 \pm 2.1 \mathrm{Bb}$ & $18.3 \pm 3.5 \mathrm{Ba}$ \\
\hline & Oxygen scavenger & $0.0 \pm 0.0 \mathrm{Cb}$ & $0.0 \pm 0.0 \mathrm{Cb}$ & $1.0 \pm 1.0 \mathrm{Cab}$ & $1.7 \pm 0.6 \mathrm{Ca}$ \\
\hline
\end{tabular}

* Mean \pm standard deviation (SD)

Non-similar uppercase and lowercase letters indicate a significant difference in columns and rows, respectively, for each temperature according to Tukey test $(P<0.05)$

at days 21 and 28 at $25{ }^{\circ} \mathrm{C}$ ), which can be attributed to very low levels of $\mathrm{O}_{2}$ and $\mathrm{CO}_{2}$ inside the packages. The packaging of barberries under vacuum also prevented the growth of fungi until the end of storage at $4{ }^{\circ} \mathrm{C}$ and until 21 days at $25{ }^{\circ} \mathrm{C}$, with the rate of decay being less than $10 \%$. It is worth noting, however, that the packages stored at $25^{\circ} \mathrm{C}$ smelled sour after 4 weeks of storage.

In the $\mathrm{N}$ packages, after 2 weeks, suitable conditions for fungal growth prevailed and the rate of decay incidence was more than the corresponding $C$ packages kept at each temperature. It has been reported that freshly harvested crops can respire under atmospheric conditions until the $\mathrm{CO}_{2}$ concentration reaches a critical level of 10 to $15 \%$; this minimum concentration is essential for preventing the growth of Botrytis species [24].

\section{Conclusion}

In this study, modified atmospheres were evaluated in terms of their impacts on the shelf life of fresh barberries packaged with PET/LDPE film for 4 weeks at 4 and $25^{\circ} \mathrm{C}$. The results showed that oxygen was the main cause of fungal decay in barberry packages, such that the packages containing the OS sachet has the least fungal decay as well as weight loss. Antioxidant activity and bioactive constituents including phenolic compounds, ascorbic acid, and anthocyanins were also better preserved in presence of OS relative to the natural atmosphere. The vacuum packaging was also suitable for prolonging the life of fresh barberries and preserving their quality. Furthermore, the results confirmed that temperature is a key factor involved in preserving the barberry fruit; increased temperature led to elevated rates of oxidative, chemical, and microbial reactions, thereby reducing the shelf life. In conclusion, it seems that the use of OS sachets or vacuum (as the second priority) in packaging combined with storage at low temperatures entails the preservation of fresh barberries for a long period, facilitating delayed consumption and exportation to other cities and countries.

\section{Acknowledgements}

The authors express gratitude to Maryam Rezaeezadeh for experiments supports. We are thankful to orchard of the Research Institute of Food Science and Technology (RIFST) for access to fresh barberry used in this study.

\section{Authors' contributions}

RN wrote the proposal, participated in sample and data collections, analyzed the data, and wrote the paper. SY participated in sample collection and materials supply, and English editing of manuscript. Both authors read and approved the final manuscript.

Funding

There was no funding.

Availability of data and materials

The dataset supporting the conclusions of this study and the information about the materials used is included within the article.

Ethics approval and consent to participate

Not applicable.

Consent for publication

Not applicable.

\section{Competing interests}

The authors declare that they have no competing interests.

\section{Author details}

${ }^{1}$ Department of Food Chemistry, Research Institute of Food Science and Technology, Mashhad, Iran. ${ }^{2}$ Department of Food Processing, Research Institute of Food Science and Technology, Mashhad, Iran.

Received: 18 August 2020 Accepted: 5 October 2020

Published online: 23 December 2020

\section{References}

1. Pinela J, Barros L, Barreira JC, Carvalho AM, Oliveira MBP, Santos-Buelga C, et al. Postharvest changes in the phenolic profile of watercress induced by post-packaging irradiation and modified atmosphere packaging. Food Chem. 2018;254:70-7. 
2. Vilela C, Santos SA, Villaverde JJ, Oliveira L, Nunes A, Cordeiro N, et al. Lipophilic phytochemicals from banana fruits of several Musa species. Food Chem. 2014;162:247-52.

3. Rodoni LM, Feuring V, Zaro MJ, Sozzi GO, Vicente AR, Arena ME. Ethylene responses and quality of antioxidant-rich stored barberry fruit (Berberis microphylla). Sci Hortic. 2014;179:233-8.

4. Caleb OJ, Mahajan PV, Al-Said J, Opara UL. Modified atmosphere packaging technology of fresh and fresh-cut produce and the microbial consequences - a review. Food Bioprocess Technol. 2013:6(2):303-29.

5. Sandarani M, Dasanayaka D, Jayasinghe C. Strategies used to prolong the shelf life of fresh commodities. J Agric Sci Food Res. 2018;9:1-6.

6. Oliveira M, Abadias M, Usall J, Torres R, Teixidó N, Viñas I. Application of modified atmosphere packaging as a safety approach to fresh-cut fruits and vegetables-a review. Trends Food Sci Technol. 2015;46(1):13-26.

7. Fagundes C, Moraes K, Pérez-Gago MB, Palou L, Maraschin M, Monteiro A. Effect of active modified atmosphere and cold storage on the postharvest quality of cherry tomatoes. Postharvest Biol Technol. 2015;109:73-81.

8. Rodriguez J, Zoffoli JP. Effect of sulfur dioxide and modified atmosphere packaging on blueberry postharvest quality. Postharvest Biol Technol. 2016:117:230-8.

9. Villalobos M, Serradilla M, Martín A, Aranda E, López-Corrales M, Córdoba M. Influence of modified atmosphere packaging (MAP) on aroma quality of figs (Ficus carica L.). Postharvest Biol Technol. 2018;136:145-51.

10. Sangatash MM, Niazmand R, Jamab MS, Modaressi AS. Development of antioxidant active films containing sodium ascorbate (SA) and ethylene vinyl alcohol (EVOH) to extend the shelf life of peanut. J Food Sci Technol. 2016;53(4):1766-83.

11. Dey A, Neogi S. Oxygen scavengers for food packaging applications: a review. Trends in Food Sci Technol. 2019;90:26-34.

12. Charles F, Guillaume C, Gontard N. Effect of passive and active modified atmosphere packaging on quality changes of fresh endives. Postharvest Biol Technol. 2008;48(1):22-9.

13. Aday MS, Caner $C$. The shelf life extension of fresh strawberries using an oxygen absorber in the biobased package. LWT-Food Sci Technol. 2013;52(2):102-9.

14. Sarraf M, Beig Babaei A, Naji-Tabasi S. Investigating functional properties of barberry species: an overview. J Sci Food Agric. 2019;99(12):5255-69.

15. Alemardan A, Asadi W, Rezaei M, Tabrizi L, Mohammadi S. Cultivation of Iranian seedless barberry (Berberis integerrima 'Bidaneh'): a medicinal shrub. Ind Crops Prod. 2013;50:276-87.

16. Mousavian DS, Niazmand R, Sharayei P. Decreasing acrylamide formation in fried potato slices using hydrocolloid coatings and bene kernel oil. J Agric Sci Tech. 2015;90:1725-34.

17. AOAC. Official methods of analysis of the Association of Analytical Chemists International. Gaithersburg: AOAC; 2005.

18. Shivembe A, Ojinnaka D. Determination of vitamin C and total phenolic in fresh and freeze dried blueberries and the antioxidant capacity of their extracts. Integr Food Nutr Metab. 2017;4:12.

19. Brito A, Areche C, Sepúlveda B, Kennelly EJ, Simirgiotis MJ. Anthocyanin characterization, total phenolic quantification and antioxidant features of some Chilean edible berry extracts. Molecules. 2014;19(8):10936-55.

20. Ahmadian-Kouchaksaraie Z, Niazmand R. Supercritical carbon dioxide extraction of antioxidants from Crocus sativus petals of saffron industry residues: Optimization using response surface methodology. J Supercrit Fluids. 2017:121:19-311.
21. Soleimanifar M, Niazmand R, Jafari SM. Evaluation of oxidative stability, fatty acid profile, and antioxidant properties of black cumin seed oil and extract. J Food Measur Character. 2019:13(1):383-9.

22. Ahmadian-Kouchaksaraie Z, Niazmand R, Najaf NM. Optimization of the subcritical water extraction of phenolic antioxidants from Crocus sativus petals of saffron industry residues: Box-Behnken design and principal component analysis. Innov Food Sci Emerg Technol. 2016;36:234-44.

23. Candir E, Ozdemir AE, Aksoy MC. Effects of chitosan coating and modified atmosphere packaging on postharvest quality and bioactive compounds of pomegranate fruit CV. 'Hicaznar'. Sci Hortic. 2018;235:235-43.

24. Koort A, Moor U, Põldma P, Kaiser C, Starast M. Comparison of regular atmospheric storage versus modified atmospheric packaging on postharvest quality of organically grown lowbush and half-highbush blueberries. Sustainability. 2018;10(11):3916.

25. Chitravathi K, Chauhan O, Raju P. Influence of modified atmosphere packaging on shelf-life of green chillies (Capsicum annuum L.). Food Pack Shelf Life. 2015;4:1-9.

26. Giuggioli NR, Girgenti V, Peano C. Qualitative performance and consumer acceptability of starch films for the blueberry modified atmosphere packaging storage. Polish J Food Nutr Sci. 2017;67(2):129-36.

27. Wani S, Hameed OB, Mir M, Hussain P, Majeed D. Effect of gamma irradiation and modified atmosphere packaging on the quality and storage stability of sweet cherry (cv. Misri and Double) under ambient and refrigerated storage conditions. J Postharv Technol. 2018;6(3):44-59

28. Duan J, Wu R, Strik BC, Zhao Y. Effect of edible coatings on the quality of fresh blueberries (Duke and Elliott) under commercial storage conditions. Postharvest Biol Technol. 2011;59(1):71-9.

29. Mendes LS, Aguayo E, Pessoa CO, Nastaro BT, Kluge RA. Enhancement of the antioxidant capacity and reduction of chilling injury in 'Douradão' peaches refrigerated under pre-storage and modified atmosphere. Acta Sci Agron. 2019;41:12

30. Vicente AR, Ortugno C, Rosli H, Powell AL, Greve LC, Labavitch JM. Temporal sequence of cell wall disassembly events in developing fruits. 2. Analysis of blueberry (Vaccinium species). J Agric Food Chem. 2007;55(10):4125-30

31. Fava J, Alzamora S, Castro M. Structure and nanostructure of the outer tangential epidermal Cell Wall in Vaccinium corymbosum L. (blueberry) fruits by blanching, freezing-thawing and ultrasound. Food Sci Technol Int. 2006;12(3):241-51.

32. Belay ZA, Caleb OJ, Mahajan PV, Opara UL. Design of active modified atmosphere and humidity packaging (MAHP) for 'wonderful' pomegranate arils. Food Bioprocess Technol. 2018:11(8):1478-94.

33. Dhinesh Kumar $\vee$, Ramasamy D, Jerish JJ. Effect of active modified atmosphere packaging material on biochemical and microbial characteristics of pomegranate arils during storage. Int J Chem Stud. 2018;6(2):95-9.

\section{Publisher's Note}

Springer Nature remains neutral with regard to jurisdictional claims in published maps and institutional affiliations.

\section{Submit your manuscript to a SpringerOpen ${ }^{\circ}$ journal and benefit from:}

- Convenient online submission

- Rigorous peer review

- Open access: articles freely available online

- High visibility within the field

Retaining the copyright to your article

Submit your next manuscript at springeropen.com 